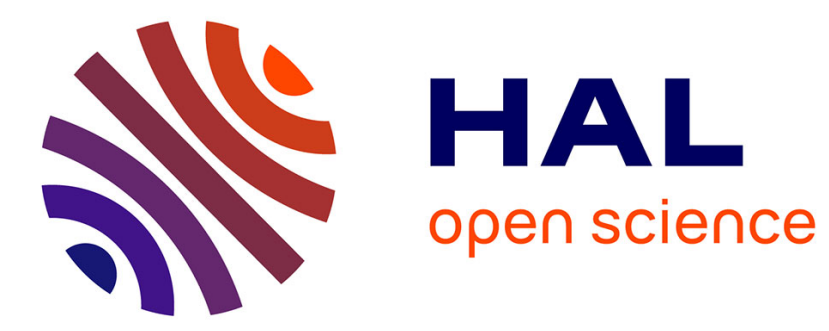

\title{
Alpha Rays Emitting Impurities in Ultra Pure Aluminum Evolution Through the Successive Refining Steps
}

\author{
M. Leroy
}

\section{- To cite this version:}

M. Leroy. Alpha Rays Emitting Impurities in Ultra Pure Aluminum Evolution Through the Successive Refining Steps. Journal de Physique IV Proceedings, 1995, 05 (C7), pp.C7-99-C7-110. 10.1051/jp4:1995708 . jpa-00254001

\section{HAL Id: jpa-00254001 https://hal.science/jpa-00254001}

Submitted on 1 Jan 1995

HAL is a multi-disciplinary open access archive for the deposit and dissemination of scientific research documents, whether they are published or not. The documents may come from teaching and research institutions in France or abroad, or from public or private research centers.
L'archive ouverte pluridisciplinaire HAL, est destinée au dépôt et à la diffusion de documents scientifiques de niveau recherche, publiés ou non, émanant des établissements d'enseignement et de recherche français ou étrangers, des laboratoires publics ou privés. 


\title{
Alpha Rays Emitting Impurities in Ultra Pure Aluminum Evolution Through the Successive Refining Steps
}

\author{
M. Leroy
}

Aluminium Pechiney, BP. 7, 38380 Voreppe, France

\begin{abstract}
Alpha rays are a major source of software errors in integrated circuits, especially in DRAM memories. A major aim of refining techniques used for the production of Ultra-pure aluminium alloys is therefore to eliminate radioactive impurities. This elimination was studied all along the refining steps from the ore (bauxite) to Ultra-pure aluminium. A major observation is that Radium isotopes accumulate in the caustic soda liquor, used for production of alumina from bauxite and in the cryolithic melt used for production of primary aluminium from alumina. Accumulated isotope Radium 228, which has a rather short half-life, disintegrates by $B-$ emission to Thorium 228, which then transfers immediately to cathodic aluminium metal. This induces a strong disequilibrium in the decay chain of Thorium 232, and, as a result, more than $80 \%$ of the total alpha-emission of Ultra-pure aluminium comes from alpha-decay of Thorium 228 and its daughters, which are not in equilibrium with Thorium 232. As a consequence, the content of Aluminium in U 238 and Th 232 (the only isotopes measured by GDMS or ICP/MS) can just give a rough order of magnitude of Alpha-emission, the Th 232 family being by far the most deleterious as regards software errors.
\end{abstract}

\section{PRESENTATION OF THE PROBLEM AND ANALYTICAL METHODS}

\subsection{Alpha rays and software errors}

It is well known since the 70's that Alpha particles (i.e. helium ions), originating from natural radioactive impurities contained in the materials constituting the ICs, or their encapsulation, are a major source of software errors (see for example Ref. 1).

Since this time, and as the level of integration of ICs has increased by several orders of magnitude, the need for materials as free as possible from $\alpha$-emitting impurities has become more and more critical.

But until now, most materials used in such applications have been specified and characterized in terms of Uranium and Thorium content, and more precisely in terms of their content in U $238+$ Th 232 isotopes [the only ones which can be measured by "normal" analytical methods (ICP/MS, GDMS ...)].

The aim of this study, which began in 1986 at PECHINEY, was to track the various Alpha-emitting impurities of Aluminium, at each step of the process, from the ore (bauxite) to the ultra-pure Aluminium used for target manufacturing, and to detect if $U 238+$ Th 232 content of these materials could adequately reflect their alpha emission potential.

\subsection{Natural Alpha-emitting isotopes}

There are 31 natural Alpha-emitting radioactive isotopes, of which 22 belong to the Uranium and Thorium families, 5 to the Lanthanide families, 3 to the Platinum family, and the last one is Hafnium 174. Among these last 9 natural $\alpha$-emitters only Samarium 147 may have a significant rate of $\alpha$-emission.

Table 1 presents the decay chains of the "Actinide" families (U 238, U 235 and Th 232). A vertical arrow means a disintegration of the isotope with emission of one Alpha particle. An oblique arrow means a 
disintegration of the isotope by transformation of a neutron into a proton with emission of a $\beta^{-}$particle (= electron).

As can be easily imagined, different natural radioactive elements can have very different physical and chemical properties, and so their behaviour during the various chemical, electrochemical and physical purification steps, from the ore to the ultra-pure metal, can be very different.

Table 1

\section{TABLE OF RADIOACTIVE FAMILIES}

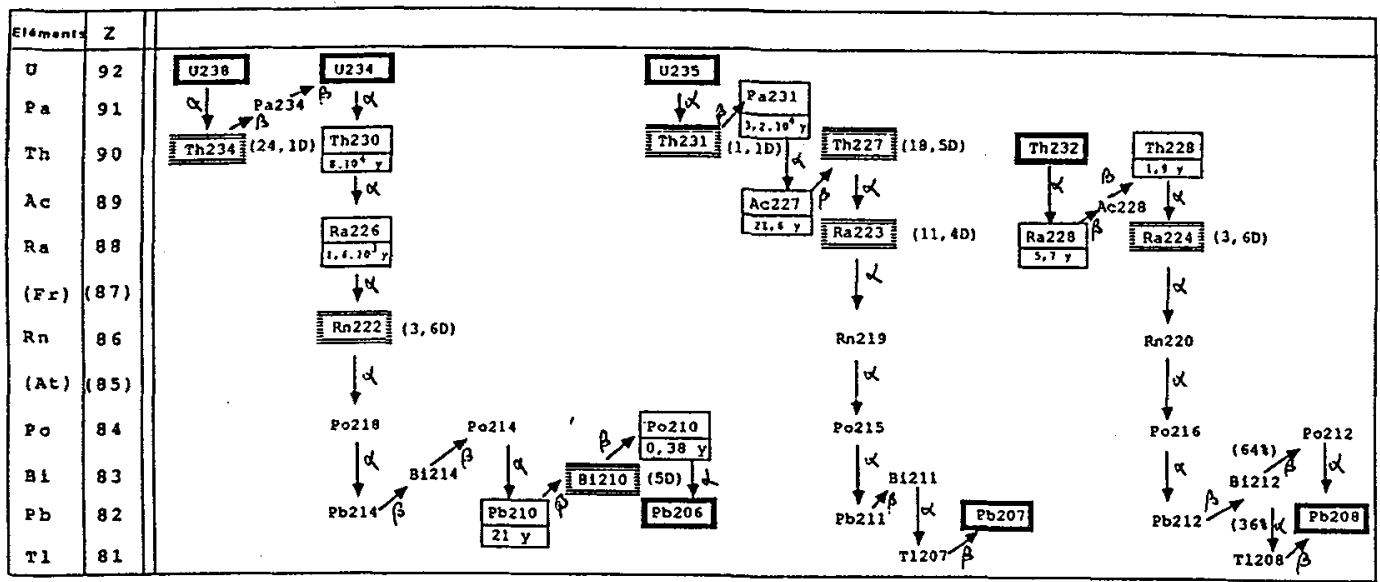

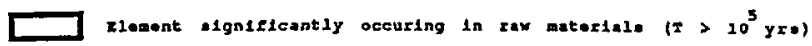

D I otope of half 11fe such af : 4 monthe $<x<10^{5}$ yre

Inotope of half 11fe sueh an : 1 day $<$ T $<30$ day*

\subsection{Purification steps, from the ore to the ultra-pure metal}

Figure 1 gives a rough description of these purification steps.

1.3.1 the only ore used worldwide for production of Aluminium (except for a few plants in CIS) is bauxite, a mixture of $\mathrm{Al}$ hydrates and other oxides, such as iron, silicon and titanium oxides or hydrates.

1.3.2 a first step in purification involves selective chemical extraction of pure Aluminium oxide (= Alumina) from bauxite, using recirculating caustic soda, with a reject of major impurities as a "red mud".

1.3.3 this pure alumina is reduced to primary aluminium metal by electrolysis in fused fluorides, using consumable carbon anodes [Hall Heroult Process].

At this stage, the Primary Aluminium produced is about $99.7 \%$ to $99.8 \%$ pure, the major impurities being $\mathrm{Fe}, \mathrm{Si}, \mathrm{Zn}, \mathrm{Ga}$.

1.3.4 this Primary metal can be further refined to a purity of at least $99.99 \%$ by either one of two processes :

- Electrolytic refining ("3 layer Process"') in a fused salt mixture (fluorides or fluorides + chlorides)

- Partial crystallisation (segregation or zone-melting) which is a physical process. 
At this stage, the nature of the impurities left behind in the refined metal, depends much upon the purification process used.

1.3.5 Ultra-pure $\left(99.999^{+} \%\right)$ aluminium for metallization of IC's needs an additional purification step, which is most often Segregation, or zone refining or sometimes Chochralsky crystal pulling.

\section{Fig. 1}

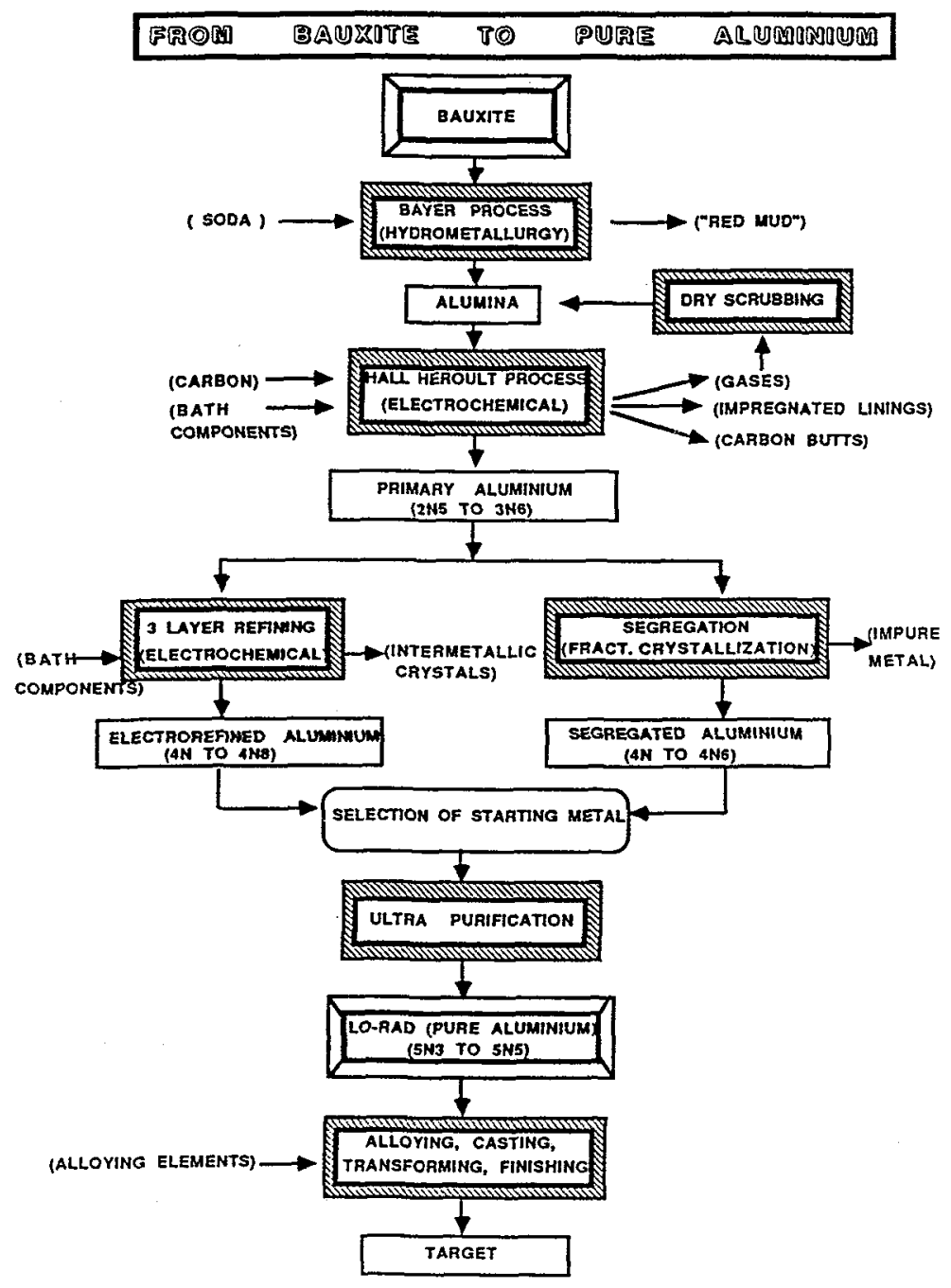




\subsection{Methods of analysis for Alpha emitters}

Isotopes with a short half-life are very rapidly in equilibrium with their longer-living parents. So subfamilies appear in the various decay chains which consist of a long-living parent and its short-living decay daughters, in which all members of the subfamily have the same rate of disintegration.

Table 2 gives these subfamilies for the Actinide decay chains, as they appear after two weeks equilibrium period.

\section{Table 2}

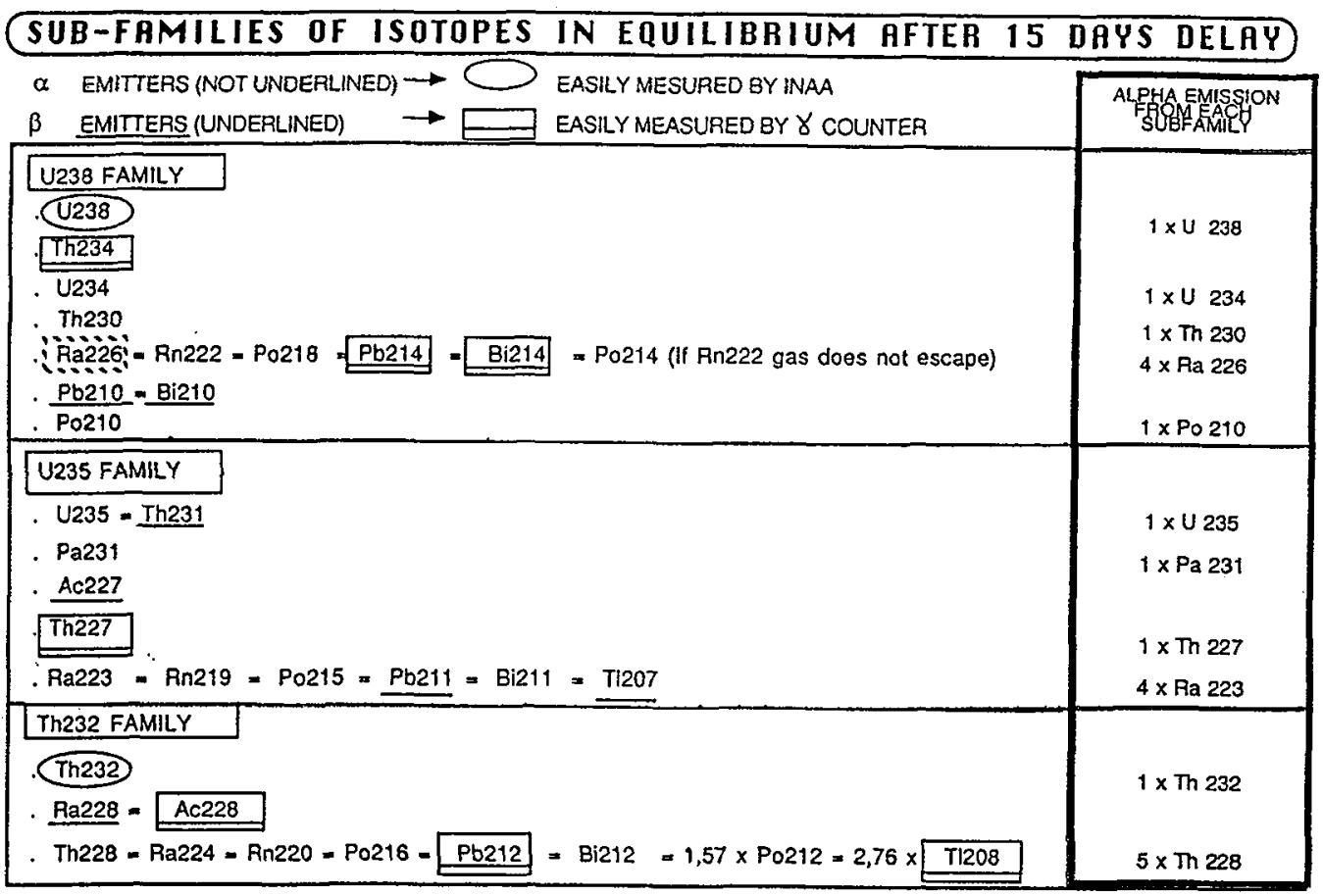

As a consequence, the rate of Alpha emission of any sample, after two weeks' equilibrium period, can be expressed (in disintegrations per minute and per gram of sample) by :

$\begin{aligned} \alpha \mathrm{dpm} / \mathrm{g}= & \mathrm{U} 238+\mathrm{U} 234+\mathrm{Th} 230+4 \times \mathrm{Ra} 226+\mathrm{Po} 210 \\ & +\mathrm{U} 235+\mathrm{Pa} 231+\mathrm{Th} 227+4 \times \mathrm{Ra} 223 \\ & +\mathrm{Th} 232+5 \times \operatorname{Th} 228 \\ & +\mathrm{Sm} 147\end{aligned}$

The measurement of total Alpha emission rate needs the determination of only 12 Alpha-emitters or of any member of their subfamilies in equilibrium with them (instead of 31 ). 
The preferred method of analysis which we used for this study includes Radiochemical separation of radioactive isotopes, and requires the dissolution of 300 to $1000 \mathrm{~g}$ of the material to be analyzed. Then selective extraction of the various chemical elements (Uranium, Thorium, Radium, Polonium) from the liquor is performed. After concentration (electroplating of Po on $\mathrm{Ag}$, anion column separation + benzene evaporation on $\mathrm{Al}$ disk for $\mathrm{U}$ and Th isotopes, co-precipitation with Barium sulphate for Radium and Lead ...) the absolute concentration of each isotope in the starting material can be measured with precision, either with an Alpha Grid Chamber (for Po 210, U 238, U 235, U 234, Th 232, Th 230, Th 228 and Th 227) or a well-type low background Gamma detector (for $\mathrm{Ra} 228$, $\mathrm{Ra} 226$, Th 234, Th 228 and $\mathrm{Pb} 210$, through their Gamma-emitting prompt decay daughters).

For some experiments, direct Gamma counting was performed, on the material to be analyzed, with our "industrial" Ultra low background Gamma Detector installed in a gallery, under the mountain, near to the Refined Aluminium production plant of MERCUS, in the French Pyrenees. Very low interferences from cosmic rays, and hence high precision of measurements, can then be achieved.

This Gamma Detector includes a $280 \mathrm{~cm}^{3}$ Germanium Detector, in a well configuration, with a $2.8 \mathrm{keV}$ resolution (FWHM), and a 8000 channel analyzer at $0.4 \mathrm{keV} /$ channel. The protecting cap of the Germanium crystal was machined from a continuously cast billet of $\mathrm{Al}+4 \% \mathrm{Si}$ aluminium alloy, made in our MERCUS plant, containing ultra-low levels of radioactive impurities : as determined by a 1000-hour count after radiochemical separation, the content in major radioactive impurities of this alloy, expressed in disintegrations per minute and per gram, is as follows :

\begin{tabular}{|ll} 
U $238<10^{-4}$ & Th $232<10^{-4}$ \\
Th $230<2.10^{-4}$ & Ra $228<3.10^{-4}$ \\
Ra $226<2.10^{-4}$ & Th $228<2.10^{-4}$ \\
Po $210<2.10^{-3}$ &
\end{tabular}

As measured by RNAA, U 238 and Th 232 contents were respectively :

$$
\mathrm{U} 238=0.15 \mathrm{ppb} \quad \text { Th } 232=0.06 \mathrm{ppb}
$$

Since then, material with equivalent or better purity has been industrially produced, and delivered to producers of low background Alpha and Gamma detectors.

\section{RESULTS}

\subsection{Bauxite [see Table 3] [From reference (2)]}

In Bauxite, which is a natural ore, all radioactive impurities of the decay chains are in equilibrium with the parents of these chains, $U$ 238, U 235 and Th 232. The Uranium and Thorium content of these ores in may vary widely, depending upon the origin of the Bauxite : Acid igneous rocks (Guinea, Brazil, Arkansas ...), which are peculiarly rich in Uranium and Thorium, Carbonate rocks (Europe, Jamaica ...), or Basic igneous rocks (India, Australia ...), which have the lowest contents of radioactive impurities And, in one and the same mine, Uranium and Thorium contents of the ore may vary considerably from one place to another. On a weight basis, Thorium 232 is always more abundant than Uranium 238, by a factor of 3 to 10 (average 4 to 5 ). 
Table 3

\begin{tabular}{|c|c|c|c|c|c|c|}
\hline \multirow[b]{3}{*}{ ORIGIN OF BAUXITE } & \multicolumn{4}{|c|}{ ACTINIDES CONTENT OF BAUXITES } & & \multirow{3}{*}{$\begin{array}{c}\text { TOTAL ALPHA } \\
\text { EMISSION } \\
\alpha \cdot \mathrm{dpm} / \mathrm{g}\left({ }^{\circ}\right)\end{array}$} \\
\hline & \multicolumn{4}{|c|}{ CONTENTS OF U AND Th (ppm) } & \multirow[b]{2}{*}{$\begin{array}{l}\text { (Th/U) } \\
\text { AVERAGE }\end{array}$} & \\
\hline & UAVERAGE & U LIMITS & Th AVERAGE & Th LIMITS & & \\
\hline $\begin{array}{l}\text { CARBONATE ROCKS } \\
\text { (Jamaica, Europe ....) }\end{array}$ & 13.0 & $6.5 / 26.7$ & 44.9 & $31.5 / 159.2$ & 3.5 & 141 \\
\hline $\begin{array}{l}\text { SHALES } \\
\text { (Georgia, Mississippi ....) }\end{array}$ & 10.5 & $5.9 / 15.4$ & 44.1 & $36.6 / / 56.7$ & 4.2 & 125 \\
\hline $\begin{array}{l}\text { BASIC IGNEOUS ROCKS } \\
\text { (India, Oregon, Ireland .... ) }\end{array}$ & 4.2 & $2.7 / 6.5$ & 20.7 & $5.0 / / 40.2$ & 5.0 & 55 \\
\hline $\begin{array}{l}\text { ACID IGNEOUS ROCKS } \\
\text { (Guinéa, Brazil. Arkansas, } \\
\text { Surinam ....) }\end{array}$ & 15.8 & $3.6 / 24.1$ & 89.1 & $54.3 / / 130.7$ & 5.6 & (222) \\
\hline AVERAGE (ppm) .......... & 11.4 & & 48.9 & & 4.3 & 138 \\
\hline
\end{tabular}

() TOTAL ALPHA $=5.84 \cdot \mathrm{U} 238(\mathrm{ppm})+1.45 \cdot$ Th232 $(\mathrm{\rho pm})$ (Natural equilibrium of U238 + Th232 with daughters) (« $\mathrm{dpm} / \mathrm{g}$ )

\subsection{Production of Alumina : The Bayer Process}

Figure 2 gives the principles of the Bayer Process.

Table 4 shows that after purification by the Bayer process, Alumina produced from Australian bauxite has very low levels of Thorium and Radium isotopes, but is much less purified in Uranium isotopes. The reasons for this lower purification of $U$ compared to Th have been studied by Sato et al (Ref. 3). But what is much more important to note, is that the natural equilibria between parent and daughter isotopes have been destroyed by this chemical process. The most intriguing fact is that the ratio of Th 228 to Th 232 has much increased from its "natural value" of 1 , to 3.5 , although these two isotopes have exactly the same chemical properties and should have behaved similarly. The origin of this "anomaly" is the following:

Radium isotopes are dissolved by caustic soda, and accumulate in the recirculating liquor without precipitating with alumina. The isotope $\mathrm{Ra} 228$, which has a rather short half life (5.7 years) can then disintegrate, to produce new "extra" Thorium 228 , which was not initially present in the bauxite ore.

The ratio of Th 228 to Th 232, in the Alumina produced, depends much upon the quantity of Radium accumulated in the BAYER loop, i.e. upon the age of the liquor and the qualities of bauxite treated during the previous years.

\subsection{Production of Aluminium metal : The Hall Heroult Process}

A description of the principles of Aluminium Reduction is given by Fig. 3. The Hall Heroult Process consists in an electrolysis of Alumina dissolved in molten cryolite at $960^{\circ} \mathrm{C}$. About $1.9 \mathrm{~kg}$ of alumina and $0.42 \mathrm{~kg}$ of carbon are needed to produce $1 \mathrm{~kg}$ of Aluminium metal.

Fluorinated fumes are emitted from the electrolytic cells, which are scrubbed by fixation on alumina and recycled to the cells. This promotes recycling of volatile impurities.

The average life of a cell lining is about 6 to 7 years, after which this lining is dismantled and replaced with a new one. The bath is recycled, which means that the "age" of the bath is often many years : so, even very minor impurities - like radioactive impurities - can accumulate in the bath, year after year. 
This is very clear from the measurements which we made : samples of alumina, bath and metal were taken from the same cell at the same moment, and analyzed three weeks later (so as to achieve equilibrium inside each subfamily). Results are given in Table 5-1.

Uranium and Thorium do not accumulate in the bath, so that these impurities are quantitatively transferred from alumina to aluminium.

Radium accumulates in the bath (compare the Radium content of alumina and bath) and is only very slightly transferred to aluminium.

The thorium 228 content of metal is more important than the quantity introduced through alumina : some "extra" Thorium 228 has been produced in the cell, by disintegration of Radium 228 accumulated in the bath, year after year.

This is exactly the same phenomenon as the one which we have identified above for the BAYER Process

Due to this "production" of new Th 228 in the cell, the ratio of Th 228 to Th 232 (expressed as disintegration rates in $\mathrm{dpm} / \mathrm{g}$ ) which was 1 in bauxite and 3.5 in alumina, increases to 6.5 in primary aluminium.

At this stage, it is quite clear that the content in Th 232 of primary aluminium cannot give a good indication of Alpha-emission from the Th 232 decay chain. Moreover, the ratio of Th 228 to Th 232 in the metal produced can be highly variable from one cell to another, depending upon the history of each cell : age of cell, age of bath, qualities of alumina used during the previous years, etc... (Table 5-2).

\section{Fig. 2 : THE BAYER PROCESS (Flow-sheet)}

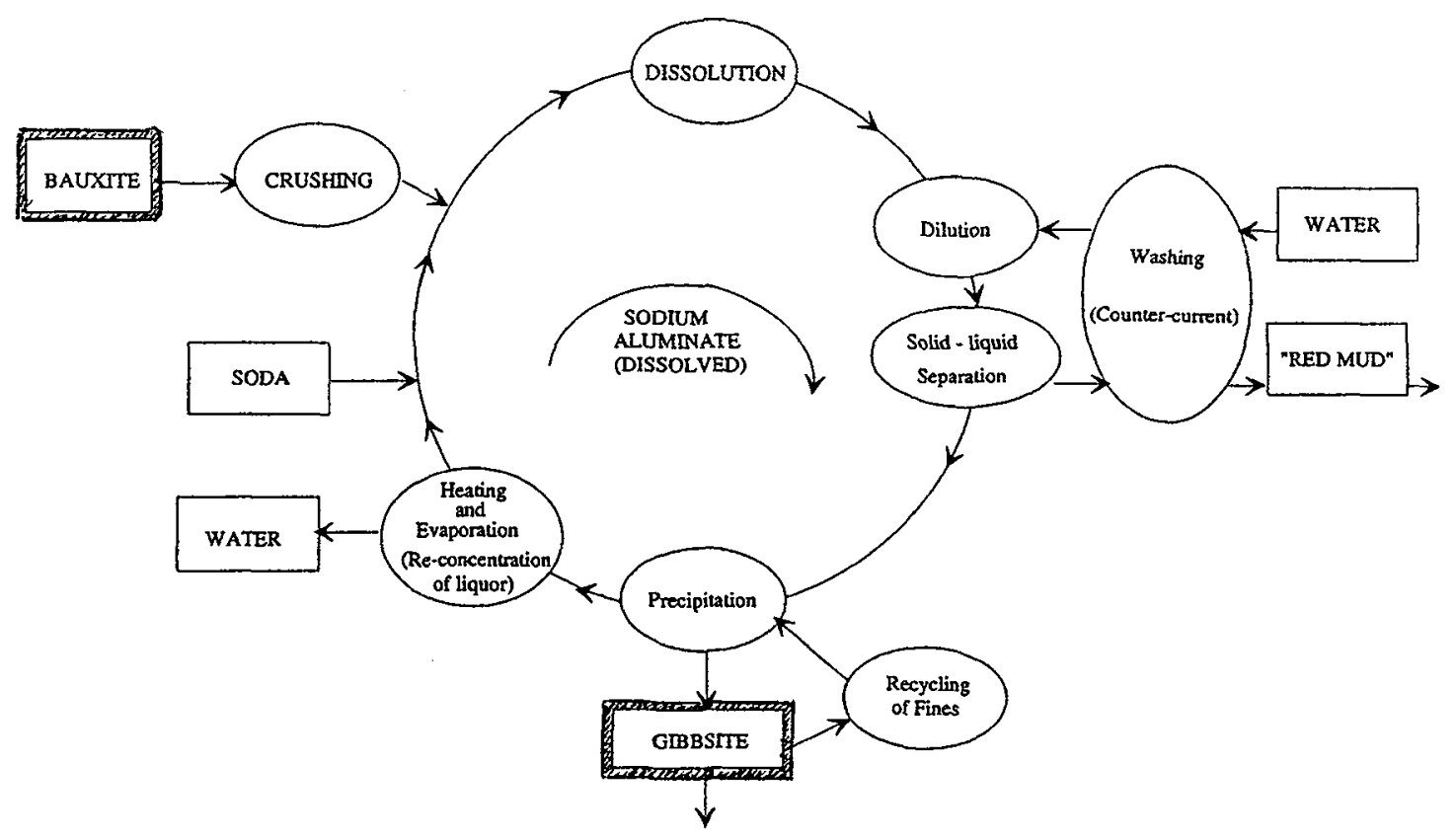




\section{Table 4 : TRACKING OF RADIOACTIVE IMPURITIES}

\begin{tabular}{|c|c|c|c|c|c|c|c|c|c|c|}
\hline & \multicolumn{5}{|c|}{ U 238 Family } & \multicolumn{3}{|c|}{ Th 232 Family } & \multirow{2}{*}{$\frac{\text { Th } 228}{\text { Th } 232}$} & \multirow{2}{*}{$\frac{\text { Th } 230}{\operatorname{Th} 2.32}$} \\
\hline & U 238 & U 234 & Th 230 & $\operatorname{Ra} 226$ & Po 210 & Th 232 & $\operatorname{Ra} 228$ & Th 228 & & \\
\hline AUSTRALIAN BAUXITE & 4 & (4) & (4) & (4) & (4) & 2.4 & (2,4) & (2.4) & 1.0 & 1.7 \\
\hline ALUMINA & 0.39 & 0.40 & 0.01 & $<0.013$ & 0.093 & 0.004 & $<0.01$ & 0.014 & 3.5 & $(2.5)$ \\
\hline PURIFICATTON FACTOR & 10. & 10 & 400 & $>300$ & 43 & 600 & $>240$ & 170 & & \\
\hline
\end{tabular}

\section{Figure 3 : THE HALL-HEROULT PROCESS}

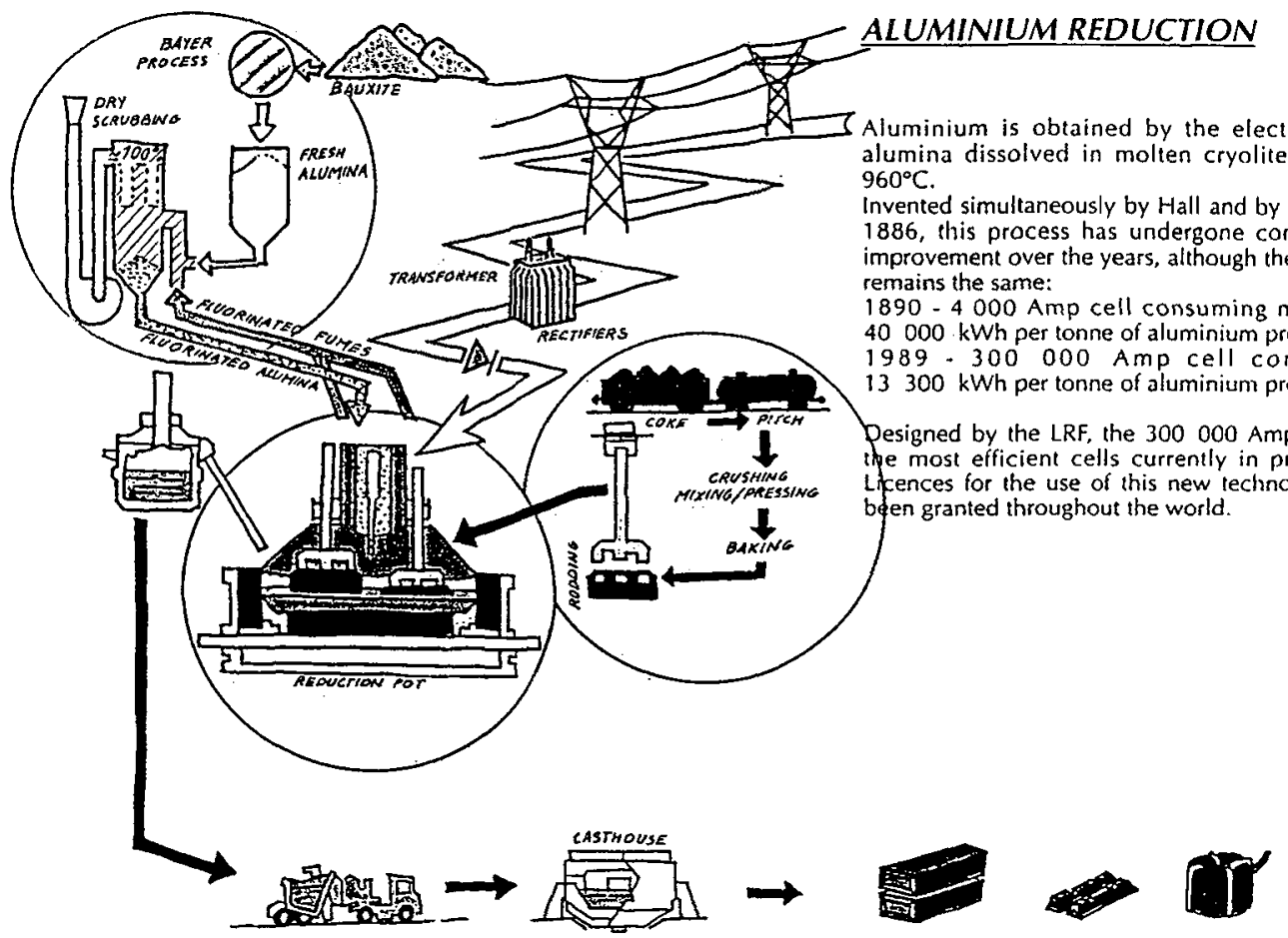

Table 5-1 : TRACKING OF RADIOACTIVE IMPURITIES

\begin{tabular}{|c|c|c|c|c|c|c|c|c|c|c|c|}
\hline & \multicolumn{5}{|c|}{ U 238 Family } & \multicolumn{3}{|c|}{ Th 232 Family } & \multirow{2}{*}{$\frac{\operatorname{Th} 228}{\text { Th } 232}$} & \multirow{2}{*}{$\frac{\operatorname{Tn} 230}{\operatorname{Tn} 232}$} & \multirow{2}{*}{$\frac{\mathrm{Ra} 228}{\mathrm{Th} 228}$} \\
\hline & U 238 & U 234 & Th 230 & Ra 226 & Po 210 & Th 232 & $\mathrm{Ra} 228$ & Th 228 & & & \\
\hline $\begin{array}{l}\text { ALUMINA } \\
\text { BATH } \\
\text { PRMMARY METAL }\end{array}$ & $\begin{array}{c}0.39 \\
0.019 \\
0.74\end{array}$ & $\begin{array}{c}0.40 \\
0.020 \\
0.77\end{array}$ & $\begin{array}{l}0.01 \\
0.007 \\
0.01\end{array}$ & $\begin{array}{c}<0.013 \\
3.79 \\
0.019\end{array}$ & $\begin{array}{l}0.093 \\
0.087 \\
0.083\end{array}$ & $\begin{array}{c}0.004 \\
0.004 \\
0.0071\end{array}$ & $\begin{array}{c}<0.01 \\
2.42 \\
0.012\end{array}$ & $\begin{array}{l}0.014 \\
0.014 \\
0.045\end{array}$ & $\begin{array}{l}3.5 \\
3.5 \\
6.5\end{array}$ & $\begin{array}{l}2.5 \\
1.75 \\
1.4\end{array}$ & $\begin{array}{l}<0.7 \\
400 \\
0.27\end{array}$ \\
\hline$\left[1.89 \times \mathrm{Al}_{2} \mathrm{O}_{3}\right] / \mathrm{Al}$ & 1.00 & 1.06 & 1.9 & $<1.3$ & 2.1 & 1.06 & $<1.6$ & 0.6 & & & \\
\hline
\end{tabular}


Table 5-2 : VARIABILITY OF COMPOSITION OF PRIMARY METAL

\begin{tabular}{|c|c|c|c|c|c|c|c|c|c|c|}
\hline & \multicolumn{5}{|c|}{ U 238 Family } & \multicolumn{3}{|c|}{ Th 232 Family } & \multirow{2}{*}{$\frac{\text { Th } 228}{\text { Th } 232}$} & \multirow{2}{*}{$\frac{\text { Th } 230}{\text { Th } 232}$} \\
\hline & U 238 & U 234 & Th 230 & Ra 226 & Po 210 & Th 232 & $\operatorname{Ra} 228$ & Th 228 & & \\
\hline CELL A & 0.74 & 0.77 & 0.01 & 0.019 & 0.083 & 0.0071 & 0.012 & 0.045 & 6.5 & 1.4 \\
\hline CELL B & 0.28 & 0.33 & 0.007 & $<0.022$ & 0.052 & 0.0075 & $<0.007$ & 0.035 & 4.7 & 0.93 \\
\hline
\end{tabular}

\subsection{Electrolytic refining of Aluminium : the Gadeau Process}

A description of an Electrolytic cell for Refining of Aluminium is given in Figure 4.

The primary aluminium to be refined is alloyed with copper so as to obtain a dense anodic layer. This dense anodic impure layer is covered with a liquid bath layer, which consists of a mixture of fused fluorides and chlorides, the nominal composition being, by weight, about $60 \% \mathrm{BaCl}_{2}+40 \% \mathrm{Na}_{2} \mathrm{AlF}_{5}$.

Aluminium transferred to the cathodic side forms a low-density liquid layer over the bath layer.

The principle of the process is the following:

2.4.1 impurities more noble than aluminium stay in the impure anodic layer and are not transferred to the bath. (They are oxidized at the anodic bath interface after aluminium).

2.4.2 Aluminium, and impurities less noble than aluminium, are transferred to the bath. (They are oxidized at the anodic bath interface before aluminium).

2.4.3 Impurities less noble than aluminium cannot be reduced and transferred to the metallic cathodic layer. So only aluminium is supposed to be transferred from the anodic impure layer to the cathodic pure layer.

A major problem is that this refining bath is not completely stable, with emission of vapours consisting of $\mathrm{NaAlCl}_{4}$ and $\mathrm{NaAlF}_{4}$ and precipitation of $\mathrm{BaFCl}$.

For this reason, the composition frequently has to be readjusted by the addition of salts $\left(\mathrm{BaCl}_{2}, \mathrm{NaCl}, \mathrm{AlF}_{3}\right.$ ...), thus introducing into the bath impurities which can then be transferred to the refined cathodic layer.

Table 6-1 shows the analytical results given by gamma spectrometry on samples taken at the same moment in the anodic impure layer, the bath layer, and the refined aluminium layer, and on samples of the salts $\left(\mathrm{BaCl}_{2}, \mathrm{AlF}_{3}, \mathrm{NaCl}\right)$ used to correct the composition of the bath.

It is clear that Alpha-emission from aluminium refined by the electrolytic process is not much improved as compared to the Alpha-emission of primary aluminium.

Once again, we notice that the electrolytic bath is rich in Radium. But, and this is a difference with respect to the Hall-Heroult Process, the Radium content of the bath compares well with the Radium content of the major ( $60 \%$ by weight) component of the bath, Barium Chloride $\mathrm{BaCl}_{2}$. Only a very small part of the Radium can come from the primary metal used as feed metal. [Which has a very low Ra Content].

The increase in Th 232 of the refined aluminium, as compared to the primary aluminium, is not as clear. We have only some indications that some part of this increase could be due to the preferential leaching, by the liquid bath, of Th 232 contained in the refractories used for the lining of the cells, and a further proportion to the content in $\mathrm{Th} 232$ of the Aluminium Fluoride $\mathrm{AlF}_{3}$ used to correct the composition of the bath.

Compared to primary Aluminium, there is a significant increase of the Th 228 content of electrolytically refined Aluminium, and this can be related to disintegration of $\mathrm{Ra} 228$ present in the bath - as it is the case for primary reduction.

But because of a larger increase in Th 232 content, the ratio Th 228/Th 232, which was 6.5 in primary aluminium, is now reduced to about 3 to 4 .

If we now consider Uranium isotopes, we see clearly that electrolytic refining is efficient as regards their purification: Uranium concentrates in the anodic impure layer and is only slightly transferred, through the bath, to the cathodic refined aluminium. 
Last, but not the least, the case of Polonium. This element, which has poorly known chemical properties, seems to be transferred from primary aluminium to refined aluminium at a highly variable rate, without any clear reason. See for reference Table $6-2$, which shows the variability of composition in radioactive impurities, of three different samples of refined aluminium taken at random from three different cells ...

\section{Figure 4 : THE GADEAU PROCESS : ELECTROLYTIC CELL}

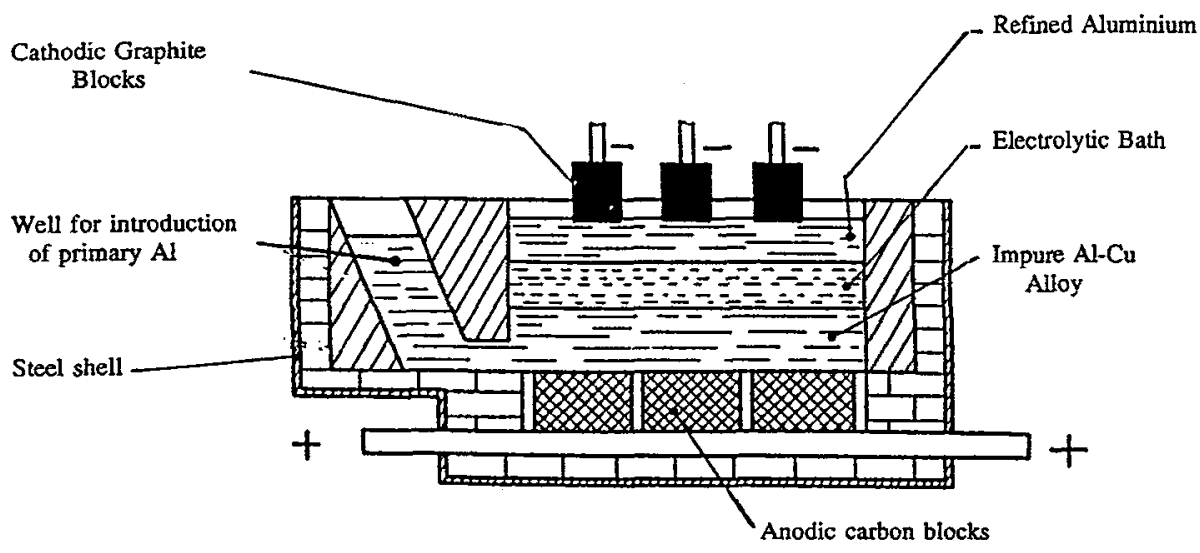

Table 6-1 : ELECTROLYTIC REFINING : TRACKING OF RADIOACTIVE IMPURITIES

\begin{tabular}{|l|c|c|c|c|c|}
\cline { 2 - 6 } \multicolumn{1}{c|}{} & U 238 & Ra 226 & Th 232 & Ra 228 & Th 228 \\
\hline IMPURE ANODIC ALLLY & 1.8 & $<0.01$ & 0.02 & $<0.02$ & 0.07 \\
\hline BATH & $<1$ & 0.70 & 0.02 & 0.55 & 0.06 \\
\hline REFINED ALUMINIUM & 0.03 & 0.01 & 0.07 & $<0.02$ & 0.20 \\
\hline NaCI SALT & - & $<0.01$ & - & 0.04 & $<0.01$ \\
\hline $\mathrm{BaCl}_{2}$ SALT & - & 0.70 & $\cdot$ & 0.53 & $<0.01$ \\
\hline $\mathrm{AlF}_{3}$ SALT & - & $<0.01$ & - & 0.05 & $<0.01$ \\
\hline
\end{tabular}

Table 6-2 : VARIABILITY OF COMPOSITION OF ELECTROREFINED ALUMNNUM

\begin{tabular}{|l|c|c|c|c|c|}
\cline { 2 - 6 } \multicolumn{1}{c|}{} & U 238 & Th 232 & Th 230 & Th 228 & Po 210 \\
\hline CELL A & 0.03 & 0.07 & (?) & 0.20 & (?) \\
\hline CELL B & 0.122 & 0.014 & 0.017 & 0.052 & 0.13 \\
\hline CELL C & 0.013 & 0.023 & 0.016 & 0.045 & 0.114 \\
\hline CELL D & 0.102 & 0.031 & 0.034 & 0.10 & 0.011 \\
\hline
\end{tabular}


The conclusion of this subsection is as follows : after electrolytic refining, Alpha-emission of aluminium is not much improved, as compared to primary aluminium.

The major emitters belong to the Th 232 decay chain, and are especially Th 228 and daughters.

Polonium 210 content is highly variable from one cell to another, without any relation with the content in other radioactive impurities, and may in some instance be a major Alpha-emitter.

\subsection{Ultra-purification by segregation}

The principles of this process were established in the sixties (see Ref. 4), and consist in the separation of a solid fraction, purified in eutectic impurities, and a liquid fraction, enriched in these impurities.

Uranium and Thorium behave as eutectic impurities, with a very low coefficient of partition between solid and liquid (about 0.005 ), and the practical coefficient of partition reaches often 0.001 to 0.0005 in our process, due to improvements giving purification factors well over those calculated from partition coefficients.

The feed-metal is generally electrolytically refined aluminium, or sometimes - depending on the specifications of the customer - a mixture of electrolytic and segregated refined aluminium.

\section{$\underline{\text { Table } 7}$}

Table 7: ULTRA PURFFICATION BY SEGREGATION : TRACKING OF RADIOACTIVE IMPURITY

\begin{tabular}{|l|c|c|c|c|c|c|c|c|}
\hline \multicolumn{1}{l|}{} & U 238 & Th 232 & Th 230 & Th 228 & Ra 228 & Ra 226 & Po 210 & Th 228 \\
\hline FEED METAL & 0.124 & 0.035 & 0.038 & 0.112 & $\leq 0.002$ & 0.002 & 0.030 & 3,2 \\
\hline IMPURE FRACTION & 0.725 & 0.201 & 0.190 & 0.593 & $\leq 0.001$ & 0.0016 & 0.028 & 3.0 \\
\hline PURE FRACTION & $0.2 .10^{-3}$ & $0.07 .10^{-3}$ & $0.08 .10^{-3}$ & $0.2 .10^{-3}$ & $\leq 0.001$ & $\leq 0.001$ & $\leq 0.002$ & 3.0 \\
\hline COEFF. OF PURIFICATION & 620 & 500 & 500 & 500 & $?$ & $>2$ & $>15$ & \\
\hline
\end{tabular}

Table 7 gives the results of a typical segregation operation, as regards radioactive impurities, and compares composition of the feed metal, the pure solidified fraction, and the impure rejected liquid metal.

What is important to notice is that the ratios Th 230/Th 232 and Th $228 /$ Th 232 do not change during the process, and that these ratios are the same in the feed-metal, in the impure liquid, and in the pure solid.

This means that measurement of Th 228 and Th 232 in the impure fraction - where they are much more concentrated - is able to give a fair image of the ratio Th $228 / \mathrm{Th} 232$ in the ultra-pure aluminium - where Th 228 content is under the limits of detection of an "industrial" (= no more than a few hours) low background gamma counting.

Another interesting point is that Polonium 210 is no longer detected in the ultra-pure metal after segregation, which means that it behaves as a eutectic impurity, and that the partition of impurities between solid and liquid is still an efficient process, for purification of impurities present at a concentration not exceeding $10^{-19}$ by weight !!

Another interesting point, as far as Polonium is concerned, is that some Polonium disappears during the segregation process, as proved by the fact that both the pure fraction and the impure fraction contain less Polonium than the feed metal.

The same is true for Radium, but in this case we think that some Radium can disappear by oxidation with air, or reaction with Graphite from the crucible (Radium is more reactive than Aluminium).

Turning now to the content in Radium isotopes of the ultra-pure aluminium, there is a problem with their limit of detection, either by Gamma-spectrometry or by Radiochemical separation and concentration.

An indication of its purification by segregation can be given by purification of Barium, which is rather similar to Radium as regards its chemical and physical properties. 
Barium is very well eliminated by segregation, with purification factors over 100 (including some elimination by oxidation, as for Radium)

We conclude from this observation that Radium content of ultra-pure aluminium should be under 0.0001 $\mathrm{dpm} / \mathrm{g}$.

Rare earths too are very well eliminated by segregation, with purification factors in excess of 200 - which completely eliminates Samarium 147 as a possible significant Alpha-emitter.

\section{CONCLUSION}

As a conclusion, it is clear that the segregation process, as perfected at PECHINEY, is able to produce Ultra-pure Aluminium with ultra low rates of Alpha-emission, under 0.01 Alpha particles per minute and per gram.

The major residual emitters are the isotope Th 228 and its rapid decay daughters, which account for more than $80 \%$ of the total Alpha-emission.

Most of this Th 228 is produced during the successive steps of purification of Aluminium, by disintegration of $\mathrm{Ra} 228$ accumulated in the purification media (caustic soda, for the Bayer Process ; fused fluorides, for the Hall Heroult Process ; fused fluorides and chlorides, for the Gadeau process).

The ratio of Th 228 to Th 232 (expressed in disintegration/mn.g) may vary very much, depending upon the "history" of the successive processes.

From this observation, one easily concludes that the total content of Ultra-pure Aluminium in $U 238+T h$ 232 , as measured by GDMS, or ICP/MS, or even RNAA, can only give a very rough estimate of Alpha-emission of the metal.

A much better method should include :

. Estimation of Th $228 / \mathrm{Th} 232$ ratio by Gamma counting on the impure liquid from the last segregation step

. Analysis of the U 238 and Th 232 content of the Ultra-Pure metal

. Calculation of the "most probable" Alpha-emission rate from these two indicators, by an approximate formula :

$$
\begin{aligned}
\alpha \mathrm{dpm} / \mathrm{g} \sim 10^{-3} \times[1.5 \times \text { U } 238(\mathrm{ppb}) \\
+0.5 \times \text { Th } 232(\mathrm{ppb}) \times\left(2+5\left[\frac{\mathrm{Th} 228}{\operatorname{Th} 232}\right](\mathrm{dpm} / \mathrm{g})\right]
\end{aligned}
$$

\section{Acknowledgements}

The author is especially grateful to Dr Jean-Louis REYSS, Research Director at the Commissariat à l'Energie Atomique at Gif-sur-Yvette (France), who performed most of the Radiochemical separations and counts needed for this study.

\section{References}

[1] T.C. MAY and M.H. WOODS. IEEE Transactions on electron devices, ED-26, n⿳⺈ 1, p. 2.

[2] ADAMS and RICHARDSON. Economic Geology. Vol. 55 (1960).

[3] C. SATO, S. KAZAMA, A. SAKAMOTO and K. HIRAYANAGI "Light Metals 1986", Proceedings, p. 11.

[4] French Patent FR 1.594.154 (1968) (Pechiney). 